\title{
Kultúrám a márkám - A munkáltatói márkaépítés és a szervezeti kultúra kapcsolata
}

\author{
Héder-Rima Mária - Dajnoki Krisztina \\ Debreceni Egyetem
}

\begin{abstract}
A TANULMÁNY CÉLJA
A munkáltatói márkaépítés tudatos alakítása számos területen fejti ki hatását a szervezeti tevékenységben annak érdekében, hogy mind a belső, mind a külső érintettek felé a vállalat legvonzóbb adottságait és előnyeit kommunikálja. A munkáltatói márkaépítés többek között érinti a kommunikációt, a szervezeti értékeket, a különböző szervezethez kötődő szimbólumokat, és ceremóniákat - azaz a szervezeti kultúra számos pontját. A kutatás során arra kerestük a választ, hogy a megfelelően kialakított szervezeti kultúra nélkül múködhet-e munkáltatói márkaépítés, illetve melyek azok a fö tényezők, amelyek az „employer branding" folyamatot a szervezeti kultúrával összekötik.
\end{abstract}

\section{ALKALMAZOTT MÓDSZERTAN}

A téma feltárását szekunder kutatásra alapoztuk. Az információk külső forrásból álltak rendelkezésre, kutatási jelentések, szakcikkek és egyéb szakirodalmak formájában. A cikk hazai és nemzetközi kutatások eredményeit foglalja össze új keretrendszerbe helyezve azokat. A tanulmányban a meglévő adatok közötti összefüggéseket, kapcsolódási pontokat leíró jelleggel vizsgáltuk, melynek következtében folyamatokat hangoltunk össze a munkáltatói márkaépítés és a szervezeti kultúra kapcsán.

\section{LEGFONTOSABB EREDMÉNYEK}

A munkáltatói márka és a szervezeti kultúra elemei kategorizálhatók és összehasonlíthatók. A feldolgozott szakirodalmi megközelítések tükrében a területek összehangolt müködtetése céljából kialakítható egy elméleti keretrendszer, ami folyamatként értelmezi a két terület müködését és egyben érzékelteti azok szoros kapcsolatát. Megállapítottuk, hogy a megfelelően kialakított szervezeti kultúra képes a munkáltatói márka megalapozására, azonban annak sikeressége leginkább azon múlik, hogy a célcsoport számára vonzó-e az, amit az adott szervezet képvisel.

\section{GYAKORLATI JAVASLATOK}

A szervezeti kultúra legfontosabb irányelvei a gyakorlatban oly módon képesek erősíteni a szervezeti müködést, hogy többek között a munkáltatói márkaépítés támogatását is szolgálják. Ennek mentén azon szervezetek, amelyek tudatos munkáltató márka kiépítésére törekednek, elsődlegesen a belső szervezeti kultúra feltárását, kategorizálását és optimalizálását kell, hogy megcélozzák, csak ezt követően célszerü annak elemeit a külső és belső érdekeltek felé kommunikálni. A munkáltatói márkaépítésnél ugyanakkor a stratégiai megvalósitás érdekében előnyös annak folyamatát is részekre bontva megtervezni és kivitelezni.

Kulcsszavak: márka, megtartás, lojalitás, trend, HR, kommunikáció

Köszönetnyilvánitás: Az Innovációs és Technológiai Minisztérium ÚNKP-19-3 kódszámú Új Nemzeti Kiválóság Programjának szakmai támogatásával készült.

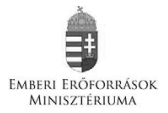

DOI: 10.15170/MM.2020.54.02.01 


\section{BEVEZETÉS INTRODUCTION}

A munkaerőpiacon végbemenő változások egyértelmüen rámutatnak arra, hogy a munkaerő-hiány, mellyel számos szervezet küzd, nagymértékben az elöregedő társadalmi korszerkezetre vezethetö vissza. Ez a trend a munkaeröpiacon azzal a visszafordíthatatlan ténnyel mutatkozik meg, hogy több munkavállaló megy nyugdíjba, mint amennyi be tud csatlakozni a munkaerópiacra. További nehezítő tényezö, hogy a munkaképes korosztály egy része külföldön vállal munkát, ezzel tovább csökkentve az elérhető munkaerő mennyiséget hazánkban. A szervezetek ezáltal azzal a kihívással néznek szembe, hogy a meglévő munkaerő megtartása és a potenciális munkavállalók bevonzásra érdekében olyan körülményeket alakítsanak ki, mellyel biztosítani tudják a hiányzó munkaerő szervezethez való vonzódását. A kereskedelemben a vásárlók szokásait és azok változását régóta kutatják, munkavállalók és munkahelyek relációjában kevésbé vannak mély gyökerei hazánkban.

A munkavállalók új generációja - mint az egyik legmeghatározóbb fogyasztói csoport - jelentős hatást fejt ki a munkaerö-piaci trendekre is. A fiatal generáció tagjainak a korábbitól eltérő igényeit igazolja az ,individualista fogyasztó”, illetve „digitális bennszülött” jelző (Törőcsik 2003). Lényeges a változó elvárásokkal korosztály szintjén is foglalkozni, ugyanis a jelenleg vezető pozícióban lévő baby boomerek helyére az X és Y generációs munkavállalók kerülnek (Pierog és tsai 2016). A célcsoportok hatékony elérésére és megszerzésére a korábban alkalmazottaktól eltérő eszközökre, módszerekre és belső szervezeti folyamatokra van szükség. A munkáltatói márkaépítés alapgondolata, hogy a munkavállalókat fogyasztói csoportként értelmezi és ennek megfelelő technikákat alkalmaz esetükben. Annak érdekében, hogy egy szervezet kívánatossá váljon a munkavállalók számára, nem elég csak a célcsoportnak megfelelő szempontokat kommunikálni, ettől sokkal fontosabb és értékesebb a vonzó és hiteles valóság kínálata, mely a szervezetben valóban jól működő rendszerek, folyamatok, belső sajátos és egyedi körülmények bemutatása mentén történő brand építését jelenti. Szigorúan kerülve a hangzatos, ám a szervezetben nem, vagy rosszul müködő tevékenységek promótálását vonzó köntösben. Ezért lényeges valamennyi szervezet számára, hogy szándékosan hatást gyakoroljon a szervezeti müködésre annak érdekében, hogy ki tudja alakítani azt a különleges és egyedi vállalati kultúrát, ami alapján pozitívan tudja magát pozí- cionálni az érdekeltjei körében (Hofstede 1991). Ehhez nem elég passzívan megfigyelni a külső és belső környezeti elemeket, hanem lehetőség szerint azok kialakulását is maguknak a szervezeteknek kell formálniuk (Barizsné 2016).

\section{A SZERVEZETI KULTÚRA SZEREPE ÉS FÖBB ELEMEI ROLE AND MAIN ELEMENTS OF ORGANIZATIONAL CULTURE}

A változó környezet a szervezeti müködést is befolyásolja. Ennek következtében szükséges a rugalmas, változásra nyitott szervezeti magatartás, mely alkalmassá teszi a teljes orgánum megfelelő reagálását a kihívásokra, a munkaerő-piacon végbemenő változásokra, a szervezeti átalakulásokra, érintettjeinek igényeinek kielégítésére.

A hatékony müködés kialakításának további záloga, az erőforrásokkal történő megfelelő gazdálkodás, munkavállalói elkötelezettség növelés és egyben a tehetséges munkavállalók megszerzése és megtartása. Ennek egy lehetséges módja, ha megfelelő munkakörnyezetet biztosít a szervezet munkatársai részére, mely kreatív módon képes azok képességeinek fejlesztésére, valamint a közös értékek kialakítására alkalmas vállalati kultúra biztosítására törekszik, melynek következtében egy közös, mindenki által elfogadott és vágyott cél felé halad a vállalat (Macey \& Schneider 2008). A szervezeti kultúra jelentősége már korábbi évtizedekben is foglalkoztatta a kutatókat. Peters \& Waterman (1986) alapján a szervezeti filozófiának és kultúrának, a csoport által közösnek vallott értékeknek jelentősége sok esetben dominánsabb a szervezet sikerességében, szemben más gazdasági vagy müszaki sajátosságokkal. Szabó-Szentgróti és tsai (2019) megerősítik, hogy az értékalapú munkaerő-kiválasztás összességében a szervezeti konfliktusok csökkentését is szolgálja, azaz erösíti az összhangot. A kultúrának és azon belül a közösen vallott értékeknek komoly a jelentősége, sok esetben dominánsabb a sikerek elérésében, mint más szervezeti sajátosság, ezért a vezetőknek tekintettel kell lenniük arra, ha a dolgozók részérôl eltérés mutatkozik a jelenlegi és az ideálisnak tartott kultúrában. A terület mérésére használható a Cameron és Quinn (2006) által kidolgozott Organizational Culture Assessment Instrument (OCAI) 6 kérdésből álló kérdőív, amelyet kutatók egyetemi hallgatók körében (Ujhelyi - Kun 2016) és szolgáltató szervezetek körében (Filep 2019) egyaránt használtak az elmúlt években. Ezek a kutatások nem csupán a szervezeti kultúra tudatos alakítására 
hívták fel a figyelmet, hanem a kultúra kialakításáért felelős egyénekre, azaz magára az emberi erőforrásra, mint kiemelkedő értékre. A szervezeti kultúrát, ha átfogó módon tekintjük, úgy a vezetés egyik alrendszereként is értelmezhetö, ahol a vezetői kontrol egyik eszközeként szolgál. A szervezeti vezetésnek foglalkoznia kell azzal, hogy a belső tagok mit gondolnak, és miben hisznek, így értékalkotó folyamatként is felfogható a szervezeti kultúra tudatos alakítása, mely egyben alkalmas arra is, hogy a pszichológiai szerződés normatív formája kialakuljon (Málovics 2004).

Mint számos társadalomtudományi fogalomnál, többféle megközelítés elfogadott, nincs egyetlen tökéletes megfogalmazás. Kroeber és Kluckhohn (1978) 160 eltérő definíciót gyüjtött össze. $\mathrm{Az}$ egyik legelső fennmaradt magyarázat Taylor (1871 in Leach 1996) nevéhez füződik, miszerint a kultúra egy összetett egész, melynek része a tudás, a hiedelmek, müvészetek, törvények, szabályzatok, hagyományok és minden szokás, amire az embereknek a társadalomban - munkaeröpiaci szempontból pedig a munkahelyeken - szükségük lehet. A kultúrához kapcsolódik a legtöbb, mindennapi élet során kialakult tapasztalatunk, viselkedésünk, gondolkodásmódunk, a tudás, a használt nyelvezet, különbözö szimbólumok, ceremóniák, közös történetek és a környezetben lévö tárgyak is (Leach 1996). A kultúrához így általános értelemben mind szellemi, mind pedig anyagi vagy tárgyi tényezők is tartozhatnak. Az anyagi jellegű tényezők fennmaradása rövidebb, azonban a kultúra szellemi alkotóelemei az emlékezetben tovább élnek, sőt generációról generációra szállhat, ezzel tartósítva azok létezését és átalakulását. Ez leginkább a kommunikáción és az emberi kapcsolatokon múlik, ezáltal változik vagy gazdagodik (Világi 1999). Schein (1997) alapján a szervezeti kultúra olyan alapfeltevéseknek az összessége, amit egy adott csoport talált ki, fedezett fel, esetleg kifejlesztett, annak érdekében, hogy képes legyen megbirkózni a külső alkalmazkodási és belső integrálási nehézségekkel. A szervezeti kultúra olyan összetett része a szervezetnek, melybe beletartoznak az emberek kapcsolataiban megfigyelt magatartási szabályok, a munkacsoportokban kialakult normák, a szervezet által szorgalmazott domináns értékek, a vezetők viselkedését meghatározó filozófia a beosztottakkal, valamint a fogyasztókkal szemben. Ezen túl ide sorolhatóak a szervezeti szabályok, sajátos folyamatok, procedúrák, valamint a szavak nélkül közvetített hangulat és klíma. Klein (2004) a szervezeti kultúrát befolyásoló tényezők közé sorolja a szervezet történetét, annak tulajdonformáját, méretét, az épületet, az irodákat, az alkalmazott technológiákat, a megjelenést, az online felületeket, az üzleti szektort, a külső környezetet, valamint az emberi erőforrás részeiként a munkavállalókat, vezetőket és alapító tagokat is. Ezt kiegészítve a kultúra olyan informális szabályoknak, normáknak, értékeknek, hiedelmeknek és szokásoknak az összessége, mely konkrétan megadja, hogy hogyan kell a kultúrát képviselő tagoknak általánosan viselkedni (Deal \& Kennedy 1982). Schwarz (1989). alapján megkülönböztethetjük a szervezeti kultúra eredeti és származékos hatásait. Míg eredeti hatásaként befolyást gyakorol az egyének magatartására, azaz a vállalati sikerek kiváltóira, a humántőkére, addig származékos hatásként belső szinten a koordinációt és irányítást stimulálja, külső szinten pedig a vállalat és környezete közötti kapcsolatra hat pl. az image-építés révén. A szervezeti kultúra ezáltal jelentős szerepet tölt be egy szervezet életében, mivel nagyban befolyásolja a mindennapok alakulását, a szervezeti tagok együttmüködését, a folyamatok kialakítását, a kommunikáció működtetését és általában a teljes szervezeti légkört és közvetlenül annak megítélését is.

\section{A MUNKÁLTATÓI MÁRKA- ÉPÍTÉS FŐBB ELEMEI KEY ELEMENTS OF EMPLOYER BRANDING}

A munkáltatói márka lényeges jellemzője, hogy azonos értékeket képvisel a fogyasztók és a munkavállalók tekintetében is. Az erős munkáltatói márka nagymértékben segíti a potenciális munkaerő vonzását, valamint a belső munkaerő elkötelezettségét is támogatja (Ásványi 2019). Erre a tevékenységre különösen nagy szükség lehet akkor, ha a munkaerőpiacon nagyobb a kereslet, mint a kínálat és a vállalatoknak egymással kell versenyre kelniük a legtehetségesebb munkavállalók megszerzése érdekében. Ehhez fontos ismerni az új munkavállalói generációk igényeit, sajátosságait. Egyetemi hallgatók körében végzett, karriermotívumokra irányuló felmérés alapján korreláció van a nagyobb jövedelem és a magasabb pozíció elérése tekintetében (Szondi 2017). Más, föiskolásokat célzó vizsgálatok (Csehné 2016) szerint a magyar fiatal munkavállalók egyidejủleg több csatornát vesznek igénybe a munkakeresés folyamán, melyek között leginkább az ismerősökön keresztüli és online mód emelkedik ki.

A munkáltatói márkaépítés központi célja, hogy a fogyasztók - emberi eröforrás gazdálkodási oldalról tekintve a munkavállalók - pozitív képzettársítást kapcsoljanak az adott szervezethez. 
A megfelelö munkáltatói márka párhuzamosan többféle területen is jótékony hatást képes kifejteni. Megkülönböztetjük a funkcionális-, a gazdasági- és a pszichológiai hasznosságot (Barrow \& Ambler 1996). Funkcionális haszonként a hasznos tevékenységek értelmezhetők, mint például az értékteremtés, gazdasági haszonként azonosíthatók azok a tevékenységek, melyek következtében közvetlenül anyagi eredményesség konstatálható (például a csökkenő toborzási költségek). Pszichológiai haszna pedig az, hogy alkalmazását követően a szervezethez tartozás érzése erősödhet a munkavállalóknak, növekedhet az elköteleződés. Ennek hatására csökken a fluktuáció mértéke, jobb lehet az együttmúködés a társosztályok között, pozitívabban nyilatkoznak a szervezettel kapcsolatban a munkatársak, stb. A munkáltatói márkaépítés tehát a funkcionális-, gazdasági- és pszichológiai hasznosság biztosításával összességében hatást gyakorol a szervezeti kultúrára is.

A munkáltatói márka összetevőit számos megközelítés taglalja, annak keretrendszerét többek között Backhaus \& Tikoo (2004) is kidolgozta (1. ábra), melynek értelmezése relatíve egyszerü módon mutatja be a munkáltatói márkaépítés lehetséges folyamatát.

\section{1. ábra: Munkáltatói márkaépítés keretrendszere Figure 1. Framework of employer branding}

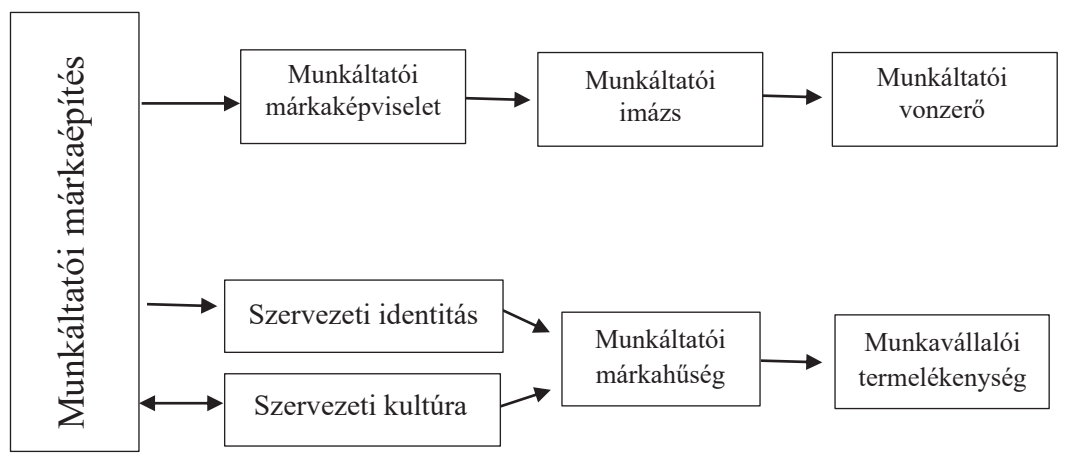

Forrás: Backhaus \& Tikoo 2004 alapján saját szerkesztés

A munkáltatói márkaépítést a modell úgy értelmezte, hogy annak két fó végeredménye várható. Egyrészt a munkavállalók vonzása, melyet a munkáltatói márka képviselete és -imázs fog meghatározni, másrészt a munkavállalói produktivitás, amit a munkáltató iránti elkötelezettség és márkahüség fog eredményezni. A munkáltató iránti lojalitásért továbbá elsődlegesen a szervezeti identitás, valamint a szervezeti kultúra felelősek. A modell egyik sajátossága, hogy a szervezeti kultúrát, mint önálló egységet szerepelteti az elmélet, ezzel azt hangsúlyozva, hogy szerves részét alkotja a munkáltatói márkaépítésnek. Megállapítható, hogy a munkáltatói márkaépítés megerősíti a szervezeti identitást és a szervezeti kultúrát, azonban utóbbi erőteljesen vissza is hat a munkáltatói márkaépítésre, tehát egy intenzív kölcsönösség figyelhető meg a két terület között
A munkáltatói márkaépítés alatt Lievens (2007) a munkáltató ismertségét, imázsát, hirnevét, a munkáltató és annak valamennyi érintettje közötti kapcsolatot érti. A Mosley (2007) által alkotott munkáltatói márka-észlelési keretrendszer a munkáltatói márka elemeit két nagy részre osztja (2. ábra). 


\section{2. ábra: Munkáltatói márkaépítés keretrendszere}

Figure 2. Framework of employer branding

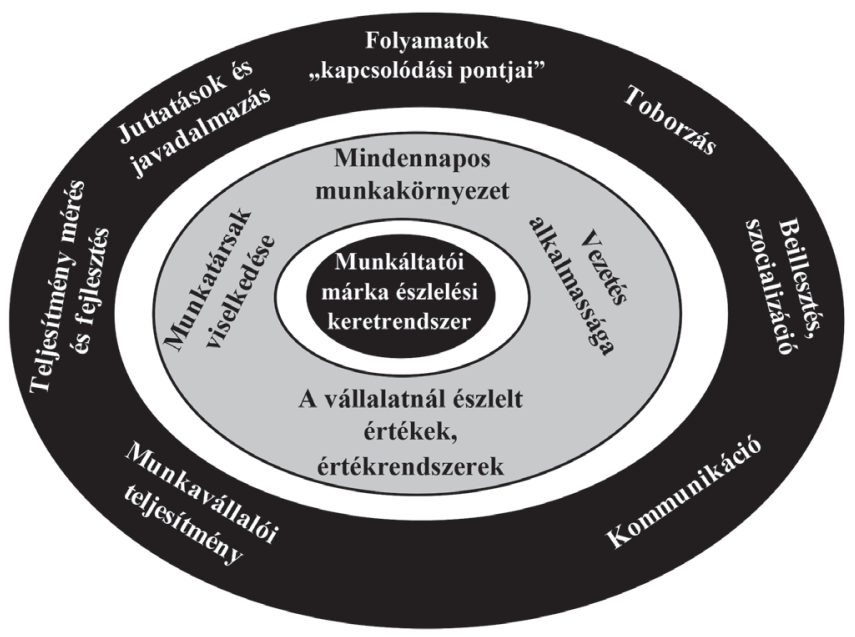

Forrás: Mosley 2007

A rendszeren belül elkülönülnek egymástól a munkavállalókat közvetlenül érintő, a mindennapi munkavégzés során tapasztalt tényezők, valamint azok, amelyek a vállalaton kívül tartózkodók számára is elérhetőek, azaz a külső érintettek szempontjából is értelmezhető folyamatok. Az ábra belső része a meglévő munkavállalók szempontjából a mindennapi tapasztalatokra épít, mint például a vezetés alkalmassága és rátermettsége, a munkakörnyezet, melyben a munkatársak mindennapjaikat töltik, a szervezetnél dolgozó többi munkavállaló viselkedése és végül, de nem utolsó sorban a szervezeten belül uralkodó értékek. Az ábra külső köre szimbolizálja a folyamatokat, azokat a munkáltatói márkaépítés során érintett területeket, melyek alapján a külső érintettek is ítéletet tudnak alkotni az adott szervezetről. Ide tartoznak a szervezeten belül megvalósuló folyamatok munkavállalókat vagy más külső feleket érintő pontjai, mint például a felvételi interjún tapasztalható légkör, a munkatársak ügyfeleket érintő megnyilvánulásai, stb. Közvetlenül ehhez kötődve a toborzás formái, a felvett új munkatársak szocializációs folyamata, a kommunikáció melyet a belső és külső célcsoportok felé képvisel a szervezet, a kialakított szolgáltatások minősége. Ezen túl árulkodó lehet a szervezeti teljesítmény, annak fokozására tett kezdeményezések, a munkavállalók fejlesztése és természetesen a juttatási formák és javadalmazási módok. A két dimenzió közötti válaszvonal ugyanakkor nem átjárhatatlan és nem szeparálja el egymástól az alkotóelemeket, hanem sokkal inkább a strukturális értelmezést segíti. Ez azt jelenti, hogy az egyes elemekkel külső és belső érintettnek is lehet kapcsolata, a modell annak hangsúlyozásában segít, hogy kire hat közvetlenebbül.

A munkáltatói márkaépítés gyakorlati megjelenését vizsgálva további kategorizálás mentén írhatók le annak elemei. Le Phan (2018) alapján elkülöníthetjük a munkáltatói márkaépítés során azokat a tényezőket, amelyeket kontrolálhat a szervezet, mint például a karrier oldal, az elérhető állások, honlap és blogfelület, szervezeti kultúra és értékek és a jelöltek irányába történő kommunikáció. A másik csoportba azok az elemek tartoznak, amelyekre közvetlen hatást tud gyakorolni a szervezet, mint például a különböző szervezeti kimutatások és vizsgálatok, melyek eredménye elérhető külső felek számára is. Ide tartoznak még a közösségi médiában való megjelenés vagy a munkavállalókat érintő történetek (pl. sikersztorik) bemutatása esetleg a különböző érdekvédelmi képviseletekkel való együttmüködés. A harmadik csoportba pedig azok a munkáltatói márkaépítés részét képző elemek tartoznak, amelyekre közvetett módon van hatása a szervezetnek, mint például a közvéleményben való szereplés, vagy a díjak és különböző elismerések elnyerésére való törekvés és ezzel kapcsolatos eredmények. 
A munkáltatói márkaépítés gyakorlati megvalósításának szempontjából többlépéses folyamatként értelmezhető. Backhaus \& Tikoo (2004) három szintre bontotta a folyamatot, melyek között elsőként a cég feladata, hogy kialakítsa a munkavállalói értékajánlatot (EVP - Employee Value Proposition). Ez egy központi üzenet, mely mentén a vállalat megkülönbözteti magát a piacon. Második lépés az értékajánlat külső és belső marketingje, melynek célja, hogy a célcsoportot megszerezze és motiválja. Harmadik lépés az értékajánlat beváltása, megvalósítása, valamint annak a szervezeti kultúrába való beépítése.

Berthon et al. (2005) alapján a munkáltatói márka hatékony kiépítése öt lépésre is bontható. Első eleme a szervezet feltárása és müködésének megértése. Második lépésben erre alapozva a munkavállalók szempontjából vonzó márkaígéret kialakítása, majd a harmadik lépés ezen ígéretek mérésére alkalmas standardok kialakítása. Negyedik szakaszba érve a mérési eszközök segítségével feltárhatók azok a folyamatok és személyek, akik a megfogalmazott értékajánlathoz nem illeszkednek és akik „eltávolítása” feltételét jelenti a hatékony munkáltatói márkaígéret megvalósításának. Utolsó lépésben pedig maga a megvalósítás és a rendszeres mérés adja meg a stabilitását a rendszernek. A munkáltatói márka magában foglalja tehát az értékeket, a kultúrát, a munkahelyi körülményeket, környezetet, sőt, ettől jóval többet is, ugyanis egy ígéretet hordoz magában a leírtak meglétét illetően, mely hitelességet kölcsönöz az érintett szervezetnek. Ez az ígéret azonban, ha az érintettek tapasztalatin keresztül nem valósul meg, kifejezetten hátrányosan hathat, a szükséges célcsoportok megnyerésében, jelentsen ez potenciális munkavállalót, ügyfélkört, befektetőket, esetleg partnerséget. Meglétének hiteles biztosítása nagymértékben fokozhatja a versenyelőnyt, a cég vonzerejét, valamint ösztönzőleg hathat a teljesítményre, az elköteleződésre és megtartásra (Randstad 2019). Biztosítása érdekében többféle folyamatmodell foglalja össze a lehetséges lépéseket. A modellek bár eltérő módon, de elméleti síkon egyértelmúen alátámasztják a szervezeti kultúrának és a munkáltatói márkának a szoros viszonyát, ugyanis nem csupán a tartalmi elemek szintjén kerül említésre a szervezeti kultúra több szakember feldolgozásában, hanem folyamat szinten is konkrétan megfogalmazásra kerül a munkáltatói márka kialakításánál.

\section{A MUNKÁLTATÓI MÁRKA- ÉPÍTÉS ÉS A SZERVEZETI KULTÚRA KAPCSOLÓDÁSI PONTJAI \\ INTERCONNECTIONS OF EMPLOYER BRANDING AND ORGANIZATIONAL CULTURE}

Annak érdekében, hogy a munkáltatói márkaépítés és a szervezeti kultúra közötti kapcsolódási pontokat feltárjuk érdemes azok elemeit sorra venni és a fenti elméleti megközelítések alapján összehasonlítani.

Az összefüggések feltárásához elsődleges alapot a szakirodalomban ismertetett elemek adtak, melyek rendszerbe történő elhelyezése egy összehangolt elméleti folyamatábra megalkotását tette lehetővé (3. ábra). 


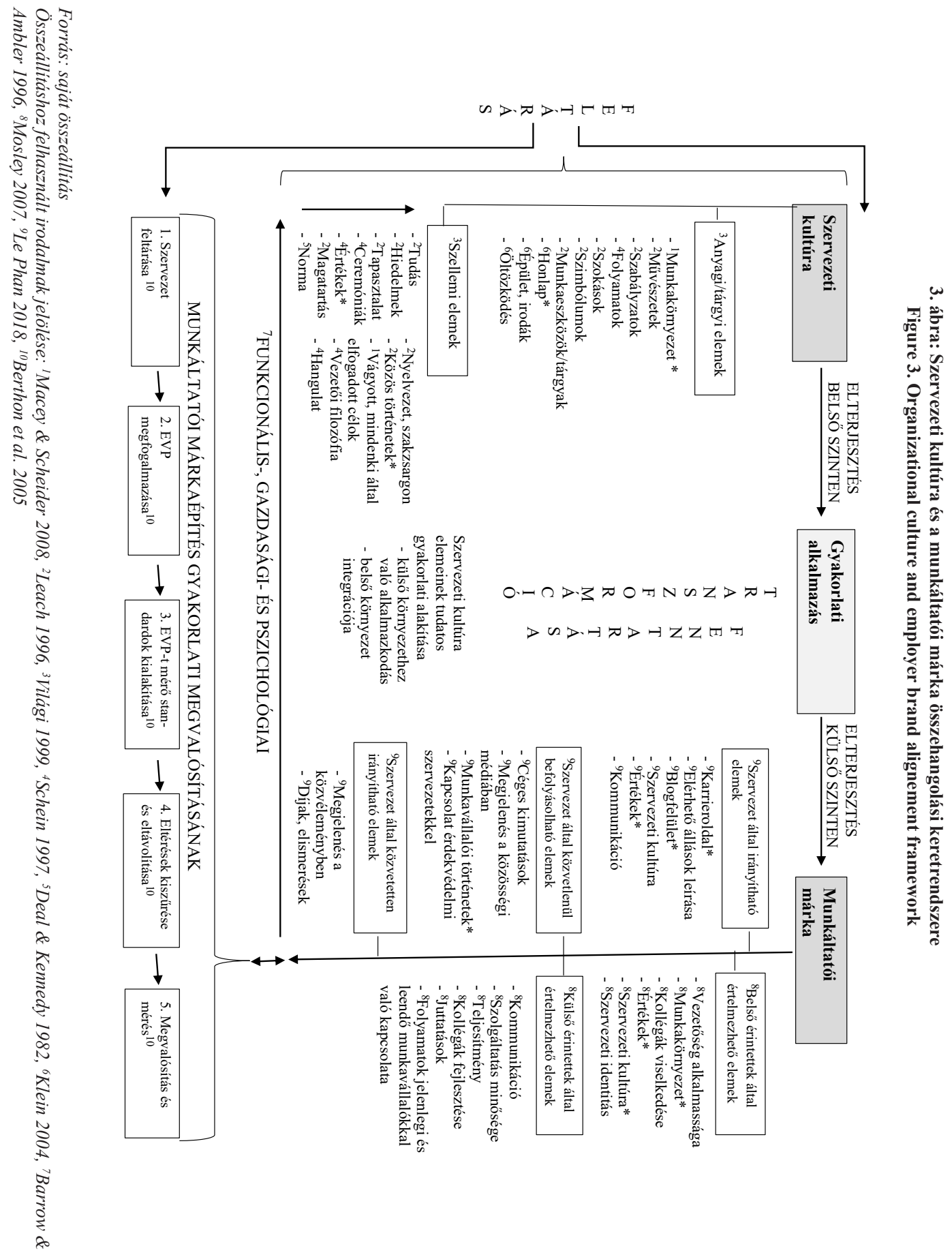


A szervezeti kultúra elemeit két nagy osztályba lehet sorolni, egyrészt az anyagi vagy tárgyi elemeket magába foglaló részekre, másrészt pedig a kézzel nem megfogható szellemi elemekre. Valamenynyi szervezet életében megtalálható mindkét típus, azonban érdemes nagyobb figyelmet szentelni a szellemi elemekre, ugyanis azok fennmaradása hosszabbtávon jellemző. Annak érdekében, hogy értékelhetővé és fejleszthetővé váljon a szervezeti kultúra, szükséges a részletes elemzése és feltárása, azaz valamennyi elemének összegyüjtése. A szervezeti kultúra azon részeit, melyek támogatják a szervezeti célkitüzések megvalósulását és segítik a múködést fontos azonosítani és tudatosan elterjeszteni a belső működésben. A két rendszer szintetizálásának ez tekinthető első lépéseként, ugyanis a kultúra elemeinek szándékos kommunikálása szervezeten belüli brand-építésként is értelmezhetö. Amennyiben ezek az elemek valamennyi érintett részéről tudatos képviseletre kerülnek, úgy könnyebb lesz annak elfogadtatása valamennyi szervezeti taggal. A gyakorlati alkalmazás során a szervezeti kultúra célja a transzformáció, azaz a szervezeti kultúra tudatos fenntartása annak megfelelően, hogy egyrészt támogassa a szervezetet a külső környezethez való alkalmazkodásban, másrészt a belső tagok összetartozását erősítse. Amennyiben a szervezet életében azonosításra kerültek azok a speciális kultúra elemek, amelyek egyedi módon, annak körülményeire és speciális jellemzőire szabva alakultak ki, úgy azokat a külvilág felé is célszerü kommunikálni, azaz a munkáltatói márka kialakításánál is segítségére lehet a szervezetnek. A két rendszer szintetizálásakor ez jelenheti a második lépést, hiszen a belső szinten sikeresen beépített, szándékosan és vonzó módon elterjesztett kultúra elemek a szervezet külső tagjai számára is továbbadhatók, mely már egyben a munkáltatói márka kiteljesedését is jelenti, azaz a külső érdekeltek felé is szándékos és egyértelmủ kommunikációba kezd a szervezet. A munkáltatói márkát alkotó elemeket többféle szempont szerint lehet kategorizálni, melyeknél több esetben átfedés található az egyes szervezeti kultúra elemekkel. Ez arra enged következtetni, hogy ezek azok az elemek, melyek kiindulópontként szolgálhatnak a munkáltatói márka gyakorlati alakítása során, hiszen azok feltehetően a kultúrában már korábban is jelen voltak.

A munkáltatói márkát alkotó tényezők három kategóriát magában foglaló felosztása mentén elkülönítjük egymástól a szervezet által irányítható elemeket, azokat az elemeket, amelyeket, ha irányítani nem is, de befolyásolni közvetlenül képes a szervezet, valamint azokat a tényezőket, amelyek befolyásolására csak közvetett módon van a szervezetnek lehetősége. Figyelembe véve, hogy a munkáltatói márka képviselete egy olyan komplex rendszert alkot, melynek következtében az funkcionális-, gazdasági-, valamint pszichológiai ráhatást is kifejt a szervezeti kultúrára, így elmondható, hogy intenzív és folyamatos befolyásolást gyakorol rá. Ennek köszönhetően elképzelhető, hogy a szervezeti kultúra egyes elemei átalakulnak, esetleg korábbiak megszünnek és újak alakulnak ki, melyek később a munkáltatói márkaépítés során is megjelennek, tehát ciklikusan alakítják egymást. Ezen túl a munkáltatói márkát alkotó elemek gyakorlatban történő alkalmazása többlépéses folyamatban értelmezhető. A 3. ábra erre vonatkozóan egy ötlépéses modellt vesz alapul, amely részletesen írja le a folyamatot. Érdekes átfedés található a szintetizáló ábra ezen részén, ugyanis az a feltárás, mely a szervezeti kultúra kialakítása során elsődleges lépés, a munkáltatói márka kialakításánál is első lépésként jelenik meg - azaz a korábban összegyüjtött adatok alkalmazhatók a folyamat ezen részénél is, sőt, akár párhuzamosan is történhet a megvalósítás. Ilyen értelemben egy kellően részletes feltárás egyrészt a szervezeti kultúra megértését szolgálja, másrészt pedig a munkáltatói márkaépítés gyakorlati megvalósításának első lépéseként is értelmezhető.

\section{ÖSSZEFOGLALÁS SUMMARY}

Megállapítható, hogy mind a szervezeti kultúra, mind pedig a munkáltatói márka tudatos alakításához szükséges a feltáró tevékenység, mely a két területet közös alapokra helyezheti és a párhuzamos megvalósítást lehetővé teheti. Az egyes területek tényezőit sorba rendezve elmondható, hogy az elemek mindkét területen kategorizálhatók, ezen túl pedig az egyes kategóriák mentén több esetben van azonosság is. Közös pontnak tekinthető a munkakörnyezet, a honlap, a szervezeti értékek és a munkavállalókat érintő közös történeteknek a megléte. Ezen megegyező elemek kiindulási alapot jelenthetnek a munkáltatói márka alakításához, hiszen a szervezeti kultúra elemként sokkal korábban kerülnek kialakulásra, akár már a szervezet létrejöttekor. Az területek vizsgálata következtében ugyanakkor olyan kapcsolódási pontok megléte is előtérbe került, amelyek alapján megalkotható az összehangolást támogató keretrendszer. Ezen belül nem csak az egyes kategóriák és az azokba sorolható elemek, hanem a tevékenységek összehangolásának folyamata és ciklikussága is ábrázolható, ami azt sugallja, hogy 
a két terület rendkívül szoros kapcsolatba hozható egymással. Az általunk összeállított koncepció (3. ábra) ezáltal alkalmas lehet a két terület közti kapcsolat szemléltetésére, a területek gyakorlati kialakítása során pedig támpont lehet arra vonatkozólag, hogy mely elemek bevonása ajánlott, illetve hogyan lehet folyamattá alakítani az egyes tevékenységeket. Ahhoz, hogy egy szervezet hiteles munkáltatói márkát tudjon kialakítani, elengedhetetlen a vállalati kultúrájának ismerete, változásainak nyomon követése, és módosulásának esetén ennek megfelelően a munkáltatói márkaépítés elemeinek is az átalakítása.

\section{HIVATKOZÁSOK REFERENCES}

Ásványi Zs. (2019), Munkaerő-biztosítási lánc menedzselésének hatékony eszközei. In: László Gy., Németh J., Sipos N.: Vezető és menedzser: Emlékkötet Farkas Ferenc születésének 70. évfordulójára. PTE, Pécs, 268-275.

Backhaus, K., Tikoo, S. (2004), "Conceptualizing and researching employer branding”, Career Development International, 9(5), 501-517. DOI: $10.1108 / 13620430410550754$

Barizsné Hadházi E. (2016), „A vezetői magatartás etikai aspektusból történő megközelítése", Taylor: Gazdálkodás- és Szervezéstudományi Folyóirat, 8(2), 49-55.

Barrow, S., Ambler, T. (1996), "The employer brand", Journal of Brand Management, 4(3), DOI: $10.1057 / \mathrm{bm} .1996 .42$

Berthon, P., Ewing, M., Li, L.H. (2005), “Captivating Company: dimensions of attractiveness in employer branding", International Journal of Advertising, 24(2), 151-173

Cameron, K. S., Quinn, R. E. (2006), Diagnosing and Changing Organizational Culture Base dont he Competing Values Framework, Business and Management Series. Revised Edition, Jossey-Bass, San Francisco CA

Csehné Papp I. (2016), „Elvárások és realitások a munka világában", Taylor: Gazdálkodás- és Szervezéstudományi folyóirat, 8(2), 5-10

Deal, T.E., Kennedy A.A (1982), Corporate Culture, Reading, Mass., Addison - Wesley

Filep R. (2019), "Examining organizational culture with OCAI among employees of a service company" Economic Sciences Tom, XXVIII(2), Oradea University Publishing House

Hofstede, G. (1991), Cultures and organizations, McGraw-Hill

Kroeber, A. L., Kluckhohn, C. (1978), Culture: A Critical Review of Concepts and Definitions. Kraus Reprint Company

Le Phan, L (2018), Employer Branding Framework: 10 parts that make up your organization's employer brand. https://b2b.kununu.com/blog/ employer-branding-framework-infographic (letöltve: 2020.01.03.)

Leach, E. (1996), Szociálantropológia, Osiris Könyvtár, Budapest

Lievens, F. (2007), "Employer Branding in the Belgian Army: The Importance of Instrumental and Symbolic Beliefs for Potential Applicants, Actual Applicants, and Military Employees", Human Resource Management, 46(1), 51-69 
Macey, W.H., Schneider, B. (2008), "The Meaning of Employee Engagement", Industrial and Organizational Psychology, 1, 3-30

Málovics É. (2004), Szervezeti kultúra és identitás. In: Czagány L. - Garai L.: A szociális identitás, az információ és a piac. JATEPress, Szeged

Mosley, R.W. (2007), "Customer experience, organizational culture and the employer brand", Brand Management, 15 (2), 123-134

Peters, T., Waterman, R. (1986), A siker nyomában. Kossuth Könyvkiadó, Budapest

Pierog A., Erdei P., Gergely É. (2016), „A Z generáció vezetőkkel szembeni elvárásai", International Journal of Engineering and Management Sciences, 1(1), DOI: 10.21791/ IJEMS.2016.1.39.

Randstad (2019), Munkáltatói márka stratégia: mi tesz igazán vonzóvá egy munkaadót? https://www.randstad.hu/workforce-insights/ employer-branding/munkaltatoi-marka-strategia-mi-tesz-igazan-vonzova-egy-munkaadot/ (letöltve: 2020.01.03.)

Schein, E.H. (1997), Organizational Culture and Leadership, Jossey-Bass Publishers, San Francisco, CA

Szabó-Szentgróti, G., Gelencsér, M., Szabó-Szentgróti, E., Berke, Sz. (2019), „Generációs hatás a munkahelyi konfliktusokban", Vezetéstudomány, 50(4), 77-88

Szondi R. (2017), „Karriertervezés vizsgálata a Debreceni Egyetemen", Köztes Európa, 9(12), $169-176$
Schwarz, G. (1989),Unternehmenskultur als Element des Strategischen Managements. Duncker $\&$ Humblot, Berlin

Törőcsik, M. (2003), Fogyasztói magatartás trendek. KJK-Kerszöv, Budapest, 349.

Turban, D.B., Cable, D.M. (2003), "Firm Reputation and Applicant Pool Characteristics", Journal of Organizational Behaviour, 24(6), 733-751

Ujhelyi M., Kun A. (2016), „Szervezeti kultúra vizsgálata OCAI modellel a Debreceni Egyetem müszaki menedzser hallgatói körében", International Journal of Engineering and Management Sciences, 1(1), DOI: 10.21791/ IJEMS.2016.1.46.

Világi R. (1999), „Szervezeti kultúra mint potenciális erőforrás", Humánpolitikai Szemle, 5-6 
Héder-Rima Mária, PhD hallgató heder.maria@econ.unideb.hu

Debreceni Egyetem

Ihrig Károly Gazdálkodás- és Szervezéstudományok Doktori Iskola

Dajnoki Krisztina, egyetemi docens dajnoki.krisztina@econ.unideb.hu

Debreceni Egyetem

Gazdaságtudományi Kar

Vezetés- és Szervezéstudományi Intézet

\section{My culture is my brand - The relationship between employer branding and organizational culture}

\section{THE AIMS OF TH PAPER}

Conscious development of employer branding has an impact on organizational activities in a number of areas, in order to communicate the most attractive attributes and benefits of the company to both internal and external stakeholders. Employer branding involves, among other things, communication, organizational values, various symbols and ceremonies associated with the organization - the aspects of organizational culture. During the research we sought to find out if employer branding can work without a well-developed organizational culture and what are the main factors that connect the employer branding process with the organizational culture.

\section{METHODOLOGY}

Exploration of the topic was based on secondary research. The information was available from external sources, like previous research reports, articles and other related literature. The study summarizes the results of domestic and international research into a new framework. In the study first we descriptive examined the relationships between the existing data, based on these results we harmonized processes related to employer branding and organizational culture.

\section{MOST IMPORTANT RESULTS}

The employer brand and organizational culture can be categorized and compared. In light of the processed literature approaches, a theoretical framework can be developed for the coordinated operation of the areas which interprets the operation of the two areas as a process and at the same time demonstrates their close relationship. We set out that a well-organized organizational culture is capable of establishing an employer brand, but its success largely depends on how attractive it is for the target group what the organisation represents.

\section{RECOMMENDATIONS}

The most important principles of organizational culture are both able to strengthen organizational functioning in practice and support employer branding. Along these lines, organizations that seek to build a conscious employer brand should primarily focus on exploring, categorizing and optimizing their internal organizational culture before communicating its elements to external and internal stakeholders. However, in the case of employer branding, it is advantageous to plan and execute its process in a piecemeal manner for strategic implementation.

Keywords: brand, retention, loyalty, trend, HR, communication 